\title{
Effect of alkaline pre-treatment on the anaerobic biodegradability of coffee husk
}

\author{
Efecto del pre-tratamiento alcalino en la biodegradabilidad anaerobia de la cáscara del café
}

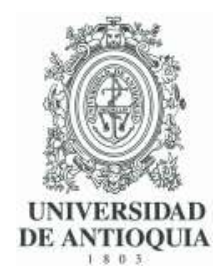

\section{K De la Cruz-Martorell (1) ', Y Gómez-Salcedo (1) 1,2, Y Santander (1) ', DJ Catagua Mera (1) 3', JCD Mendoza (1) ', I. Pereda-Reyes (1) 1}

${ }^{1}$ Facultad de Ingeniería Química, Universidad Tecnológica de La Habana “José Antonio Echeverría” (Cujae). C. P. 11901. 114 Street. Marianao, Cuba.

${ }^{2}$ Escuela de Ingeniería Química, Facultad de Ciencias Matemáticas, Físicas y Químicas. Universidad Técnica de Manabí. Av. Urbina y Che Guevara. C. P. 130105. Portoviejo. Manabí, Ecuador.

${ }^{3}$ Escuela Superior Politécnica del Litoral (ESPOL), Centro de Investigaciones Biotecnologicas del Ecuador (CIBE), Campus Gustavo Galindo km. 30.5 Vía Perimetral. P.O. Box 09-01-5863. Guayaquil, Ecuador.

\section{CITE THIS ARTICLE AS:}

K. De la Cruz, Y. Gómez, Y. Santander, D. J. Catagua, J. C. Dustet, I. Pereda, “Effect of alkaline pre-treatment on the anaerobic biodegradability of coffee husk", Revista Facultad de Ingeniería Universidad de Antioquia, no. 92, pp. 36-41, Jul-Sep 2019. [Online]. Available: https://www . doi.org/10.17533/ udea.redin. 20190516

\section{ARTICLE INFO:}

Received: February 20, 2019

Accepted: May 17, 2019

Available online: May 17, 2019

\section{KEYWORDS:}

Anaerobic digestion, alkaline pre-treatment, methane yield, lignocellulosic biomass, polyphenols

Digestión anaerobia, pre-tratamiento alcalino, rendimiento de metano, biomasa lignocelulósica, polifenoles
ABSTRACT: The present paper deals with the mono-digestion of coffee husk during the operation of batch reactors and semi-continuous stirred tank reactor (S-CSTR) using both pre-treated residual at $3 \% \mathrm{Ca}(\mathrm{OH})_{2}$ and without pre-treatment. The semi-continuous operation was carried out in 4 stages at different organic loading rate (OLR, [gvs $\left.\mathrm{L}^{-1} \mathrm{~d}^{-1}\right]$ ) and hydraulic retention time (HRT, [d]) (OLR:HRT) ratios (0.1:90, 0.2:90, 0.2:45 and 0.2:30). As a result of the pre-treatment, up to $223 \%$ of the organic matter solubilisation was obtained. However, pre-treatment did not provide better results in biodegradability, observing a negative trend in methane yield when operating in S-CSTR, due to the accumulation of compounds from the fractionation of the lignin as is the case of polyphenols. The operation was further developed using the residual without pre-treatment. The highest methane yield was obtained at 45:0.2 when using the residual without pre-treatment being with $277 \mathrm{~mL}_{\mathrm{CH}}$ $\mathrm{g}_{\mathrm{vs}^{-1}}$, for a methane productivity of $1.1 \mathrm{~L} \mathrm{~L}^{-1} \mathrm{~d}^{-1}$. When implementing the 30:0.2 ratio, a biomass washout was observed in the system, so it is recommended to operate at low OLR and high HRT when treating solid coffee wastes.

RESUMEN: La biodegradabilidad de la cáscara del café durante la operación de reactores en discontinuo y en tanque agitado semi-continuo, se evaluó empleando el residual pre-tratado con $\mathrm{Ca}(\mathrm{OH})_{2}$ al $3 \%$ y sin pre-tratar. La operación en régimen semi-continuo se llevó a cabo en 4 etapas empleando relaciones de carga orgánica volumétrica (COV. [ $g_{\mathrm{SV}} \mathrm{L}^{-1}$ $\mathrm{d}^{-1}$ ]) y de tiempo de retención hidráulico (TRH, [d]) (COV:TRH) de 0,1:90; 0,2:90; 0,2:45 y $0,2: 30$. Como resultado del pre-tratamiento se obtiene hasta $223 \%$ de solubilización de la materia orgánica. Sin embargo, el pre-tratamiento no brindó mejores resultados en la biodegradabilidad, observándose una tendencia negativa en el rendimiento de metano en la operación en semi-continuo, debido a la acumulación de compuestos resultantes del fraccionamiento de la lignina como es el caso de polifenoles, por lo que se decidió continuar empleando el residual sin pre-tratar. El mayor rendimiento de metano se obtuvo a 45:0,2 cuando se utilizó el residual sin pre-tratar obteniéndose $277 \mathrm{~mL}_{\mathrm{CH}_{4}} \mathrm{~g}_{\mathrm{SV}^{-1}}$, para una productividad de metano de 1,1 $\mathrm{L} \mathrm{L}^{-1} \mathrm{~d}^{-1}$. Al implementar la condición de 0,2: 30 se observó un lavado de biomasa en el sistema por lo que se recomienda operar a bajas COV y elevados TRH al tratar residuales sólidos cafetaleros.

\section{Abbreviations:}

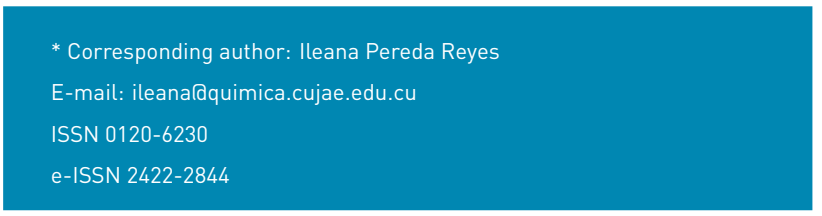

OLR: organic loading rate

HRT: hydraulic retention time

S-CSTR: semicontinuous stirred tank reactors

CC: coffee husk without pre-treatment 
CC-p: coffee husk pre-treated

TS: total solids

VS: volatile solids (SV, in Spanish)

BMP: biochemical methane potential

VFA: volatile fatty acid

TIC: total inorganic carbon; $\mathbf{w} / \mathbf{w}$, wet weight; $\mathbf{w} / \mathbf{v}$, weight/volume; d.b., dry basis.

\section{Introduction}

The consumption of coffee as a stimulant beverage is a global paradigm, its use has increased over time mainly in industrialized or developed countries. The coffee industry releases enormous amounts of by-products that are rich in carbohydrates, proteins, pectin and bioactive components that result in low-cost renewable resources [1].

A method called "benefit" is used to obtain the grain. This can be done in two ways: dry and wet. Most producing countries, including Cuba, use the wet method to obtain clean grain. However, this route generates large volumes of liquid and solid residuals, which are a source of severe pollution because of the high pollution load they have [2]. In recent years, there has been increased interest in the comprehensive use of this waste through alternatives that contribute to environmental protection [3]. Anaerobic digestion emerges as an effective way to obtain alternative or renewable sources of energy and also significantly reduces greenhouse gas emissions into the atmosphere.

Due to the complex chemical composition of the coffee cherry (content of lignin, hemicellulose, cellulose, polyphenols, caffeine and tannins, etc.), the solid residues of this fruit are characterized as lignocellulosic materials, which limits its biodegradability and compromises the proper development of anaerobic digestion. These wastes can produce energy in three forms: liquid fuels such as bioethanol, gaseous fuels such as biogas and electricity by combustion [4].

The application of a pre-treatment emerges as a resource to fractionate the lignocellulosic material. When a greater solubilisation of the organic matter present is achieved, an increase in methane yield would be expected by stimulating the hydrolysis process [5]. However, the application of a pre-treatment frequently produces the degradation of compounds that can act as inhibitors: organic acids (acetic, formic and levulinic), furans derivatives (furfural, among others) and phenolic compounds [6], affecting above all cellular physiology and often decreasing viability and productivity [7].

Among the pre-treatments that have the greatest influence due to their nature against biomass with refractory compounds are chemical pre-treatments, thermal and the combination of these. Alkaline pre-treatment is typically used in lignocellulosic materials with a high lignin content [8]. Therefore, the aim of the present paper is to assess the anaerobic biodegradability of the pre-treated and not pre-treated coffee husk during the operation of both batch and semi-continuous stirred tank reactors (S-CSTR).

\section{2. Material and methods}

\subsection{Feedstock and inoculum}

The raw material used was coffee husks from fruits of the Coffea arabica variety, harvested manually in the 2017 coffee harvest at the Sabanilla pulper, Artemisa, Cuba. This residue was milled and screened to a diameter of less than $10 \mathrm{~mm}$. The inoculum comes from the industrial wheat straw processing plant of the EBR German company, with a TS content between $24-32 \%$. It was kept refrigerated at $4^{\circ} \mathrm{C}$ until its use. The active biomass was then solubilized, bio-suspended and hydrolysed in the laboratory using a patent-protected procedure. The determination of total solids (TS), volatile solids (VS) and chemical oxygen demand (COD) and soluble COD (sCOD) were performed following the standards established by APHA-AWWA-WEF standardized methods [9]. The lignocellulosic composition (cellulose, hemicellulose and lignin) of the coffee husk was determined according to ANSI/ASTM D1103-77 and ANSI/ASTM D1106-96 [10, 11].

\subsection{Experimental set-up}

\section{Discontinuous system (Biochemical Methane Potential (BMP) test)}

The assembly of the anaerobic digesters was developed according to the German Standard [12], under mesophilic regime $\left(37 \pm 1^{\circ} \mathrm{C}\right)$ with a digestion time of 15 days, using as ratio $g_{v s}$ substrate/gvs inoculum equal to $0.1 / 1$. Two variants were studied, one with untreated coffee husk (CC) and the other pretreated (CC-p) with $1 \mathrm{~L} \mathrm{CalOH})_{2} / 100 \mathrm{~g}_{\mathrm{TS}}$ of the residue, for 6 hours at $50^{\circ} \mathrm{C}$. The concentration of the alkaline solution was $3 \%(\mathrm{w} / \mathrm{v})$. Each case study was developed in duplicate in $500 \mathrm{~mL}$ capacity glass containers occupying an effective volume of $320 \mathrm{~mL}$.

The specific methanogenic capacity (SMC) test was used to account for methane production. Through a system of calibrated glass eudiometer tubes with liquid displacement operating under vacuum conditions, the gas ascends in contact with an alkaline solution of $(15 \% \mathrm{NaOH})$. The displacement occurs when the biogas, being in contact with the solution, the content of $\mathrm{CO}_{2}$ present dissolves and finally the $\mathrm{CH}_{4}$ succeeds in replacing it. This event is recorded with the $\mathrm{NaOH}$ volume variation observed in each measurement and the result obtained is normalized 
according to VDI 4630 [12]. The reactors were manually stirred before making the measurements of the volume of liquid displaced in the columns. Methane production was reported as average values of each experience performed in triplicate.

\section{Semi-continuous system}

The S-CSTR was operated at $37 \pm 1^{\circ} \mathrm{C}$ using a $6 \mathrm{~L}$ capacity reactor in which an effective volume of $4 \mathrm{~L}$ was occupied. This reactor has a mechanical agitation system and a coil in charge of maintaining the temperature in the medium. The feed was supplied daily manually and the experimentation was divided into four stages, taking into account the OLR [gvs $L^{-1} d^{-1}$ ]:HRT $\left[d^{-1}\right]$ ratio of $0.1: 90$; $0.2: 90 ; 0.2: 45$ and $0.2: 30$. The experimental period began with the feeding to the CC-p and OLR system that varied between 0.1-0.2 gvs $L^{-1} \mathrm{~d}^{-1}$, with the change of substrate to $C C$ the system was maintained with OLR of $0.2 \mathrm{gvs}_{\mathrm{vs}}^{-1} \mathrm{~d}^{-1}$.

A recirculation in fraction $1 / 3$ of the effluent was applied from the beginning of the use of $\mathrm{CC}$. Methane production was obtained by displacing a $19.5 \mathrm{~cm}$ diameter hood with a total volume of $3.94 \mathrm{~L}$. The volume displaced in the hood is the daily production of methane. Before the gas reaches the hood, it passes through a bottle containing a $15 \%$ $\mathrm{NaOH}$ solution to remove the $\mathrm{CO}_{2}$.

Sampling began when the S-CSTR reactor was started-up. The reactor was previously shaken for 10 minutes before the biomass sampling. The effluent was extracted from the surface of the reactors with a syringe. The liquid and solid phases were separated by centrifugation for 10 minutes at 10,000 rpm and the supernatant was filtered through a microfiber filter $(0.45 \mu \mathrm{m})$. Both phases were stored in polyethylene tubes at $4^{\circ} \mathrm{C}$. The extracted effluent was analysed by measuring: $\mathrm{pH}$, temperature, TS, VS, organic matter content inside the reactor and volatile fatty acids to total inorganic carbon (VFA/TIC) ratio.

\subsection{Determination of total polyphenolic content}

In order to determine the content of total polyphenols in the extracts, the Folin-Ciocalteu colorimetric technique was applied [13]. A spectrophotometer (Rayleigh, model VIS-7236, Chinal was used to measure absorbance at 765 $\mathrm{nm}$. The results were expressed in gallic acid equivalents per gram of total solids (mg GAE $g_{T^{-1}}$ ). The value of the total polyphenolic concentration was determined from a calibration curve adjusted to a linear model.

\subsection{Determination of VFA/TIC ratio}

The ratio of the volatile fatty acids to total inorganic carbon (VFA/TIC) is an alkalinity ratio at two-point titration measurement. This ratio was determined following the method described by [14]. The samples were first titrated with $0.1 \mathrm{~N}$ sulphuric acid to $\mathrm{pH} 5.0$ and then further to $\mathrm{pH}$ 4.4. The volume of sulphuric acid consumed to reach the respective $\mathrm{pH}$ values is equivalent to the amount of volatile fatty acids (VFA) and the amount of total inorganic carbon (TIC). The ratio of VFA to TIC provides information on the stability of the fermentation process. A ratio of $\leq 0.3$ is recommended for a stable anaerobic fermentation.

\section{Results and discussion}

\subsection{Characterization of the raw material}

Characterization of inoculum and substrate (coffee husk) not pre-treated and pre-treated with alkaline solution was determined based on volatile solids and total solids content (Table 1).

Table 1 Characterization of CC and CC-p and inoculum

\begin{tabular}{llll}
\hline & CC & CC-p & Inoculum \\
\hline TS (g/g w/w) & 0.13 & 0.09 & 0.02 \\
VS (g/g w/w) & 0.12 & 0.08 & 0.01 \\
$\%$ \%S (d.b.) & 91.62 & 88.42 & 56.02 \\
\hline
\end{tabular}

Other authors who worked with coffee residuals reported results very similar to those shown in table 1 with \%VS between 90 and $93[2,15,16]$. Moreover, when comparing these results with those of other lignocellulosic materials, such as corn straw containing $91.6 \%$ VS or bagasse with $91.9 \%$ [4], it can be concluded that this residual presents similar characteristics to other agro-industrial residues.

When applying the pre-treatment to the substrate (CC-p), a slight decrease in the volatile solids of the residual was observed, since organic compounds that were not accounted for in the gas may have been volatilized. With respect to the inoculum, it presents a volatile solids content higher than $50 \%$ recommended for use as a source of active biomass to the system [12].

The determination of the lignin, cellulose and hemicellulose content in coffee husks would confirm the lignocellulosic character of this residual (Table 2).

As observed, the lignin content is in accordance with what has been reported by other authors for this substrate $[1,2,17]$ that refer values of $17 \pm 1.5 \%$. This value may contain alterations in the same crop species influenced by factors such as growth stage, genotype and environmental conditions, which may influence both the yield and efficiency of the process [18]. 
Table 2 Lignocellulosic fibre content of coffee husks

\begin{tabular}{ll}
\hline Component & $\%$ \\
\hline Ligning & 16.5 \\
Cellulose & 36.5 \\
Hemicellulose & 19.0 \\
\hline
\end{tabular}

\subsection{Effect of alkaline pre-treatment on the biodegradability of coffee husks. Biochemical Methane Potential assessment}

The SCOD of the pre-treated coffee husk (CC-p) increased by $223 \%$ when applying the alkaline pre-treatment. As a consequence, when performing the anaerobic test in batch assays, the maximum methane yield value $\left(274 \mathrm{~mL}_{\mathrm{CH} 4}\right.$ $\mathrm{g}_{\mathrm{vS}^{-1}}$ ) was attained in the reactor containing $\mathrm{CC}-\mathrm{p}$, with an increase of $7.3 \%$ compared to the reactor containing the residue without pre-treatment with significant differences (p-value $<0.5)\left(255 \mathrm{~mL}_{\mathrm{CH}_{4}} \mathrm{~g}_{\mathrm{vs}^{-1}}\right)$.

\subsection{Effect of alkaline pre-treatment on semi-continuous anaerobic digestion}

The semi-continuous systems operated over a digestion period of 112 days. Figure 1 shows the behaviour of methane yield for each volumetric organic load and the different substrates.

The initial organic load selected was $0.1 \mathrm{gvs} \mathrm{L}^{-1} \mathrm{~d}^{-1}$ and was maintained throughout 27 days. During this period, $\mathrm{pH}$ value was $7.3 \pm 0.3$, which indicate a regulatory capacity of the hydrogen potential of the anaerobic system despite this is not a control parameter to take immediate solutions if acidification occurs.

In Figure 1, stage I corresponds to the start-up of the system. In stage II, the OLR was increased to $0.2 \mathrm{gvs}$ $\mathrm{L}^{-1} \mathrm{~d}^{-1}$ and remained at this value during the rest of the experimental period. Due to the characteristics of the solid coffee residues, it is very important to observe the development of the anaerobic process, since it is possible to transform some compounds into toxic substances that would partially or totally inhibit the biodegradation process. Previous unreported experiences of this research group demonstrated that higher OLR prompt the system to fail.

During the addition of CC-p, in the second stage, an average value of $163.3 \mathrm{~mL}_{\mathrm{CH}_{4}} \mathrm{~g}_{\mathrm{vs}^{-1}}$ was obtained, a lower result than that obtained in a discontinuous regime with a decrement of $41 \%$. For this reason, it was decided to swift to untreated coffee husk (CC). With this change, a $34 \%$ increase in methane yield was observed, although it is $14.5 \%$ lower than expected one for this residual.
It should also be noted that with the change to $\mathrm{CC}$ (stage II-III) the methane yield began to show an increasing trend, that remained stable in the range of $190.0-365.0$ $\mathrm{mL}_{\mathrm{CH}_{4} \mathrm{gVS}^{-1}}$ with an average of $277.0 \mathrm{~mL}_{\mathrm{CH}_{4}} \mathrm{gVs}^{-1}$ over the course of stage III. Accordingly, the methane yield was increased by $8.6 \%$ in relation to the discontinuous test. With the increase in the solubilized organic matter and fractionating lignin, an increase in methane yield was expected, due to microbial biomass would have access to cellulose and hemicellulose to hydrolyse it.

However, this result is similar to the one reported by [19] which applied an alkaline pre-treatment with $\mathrm{NaOH}$ in a semi-continuous assay. Consequently, the reactor showed an inhibition by the accumulation of compounds resulting from the fractionation of the lignin with the pre-treatment. Other authors report that lignin degradation leads to the release of phenolic compounds at higher concentrations. These phenoliccompounds have a negative impact on the hydrolysis of a substrate [6]. Investigators [1] point out that a high concentration of polyphenols inhibits the fermentation process. These elements are present in coffee and its residues.

The characterisation of the effluents in the different stages, report polyphenols content when using $\mathrm{CC}$ and CC-p of 23.1 and $58.4 \mathrm{mg}_{\mathrm{GAE}} \mathrm{g}_{\mathrm{TS}^{-1}}$, respectively. There was a higher accumulation of these compounds when the pre-treated residual was used as a sole substrate, which can be attributed to the generation of toxic substances while pre-treated or hydrolysed during the AD. As effect, methane yield during the CC-p feed stage was lower than the one obtained for $\mathrm{CC}$ substrate. The alkaline or thermal pre-treatments can increase the concentration of phenolic compounds, i.e. $p$-coumaric acid, ferulic acid, vanilic acid and 4hydroxybenzoic acid, to inhibitory levels [6].

In stage IV, the strategy led to reducing the solids content and the inhibitory effect with a higher dilution to induce a decrease in the concentration of toxic substances in the system. During the experimental period, the methane productivity rate $\left(\mathrm{PCH}_{4}\right)$ increased over time with values ranging between 0.4 and $1.6 \mathrm{~L} \mathrm{~L}^{-1} \mathrm{~d}^{-1}$ (Figure 2). This shows the way in which the active biomass responds to the daily addition of substrate to the system, that is, the rapidity with which the microorganisms consume the volatile solids. Other authors reported similar values when they treated fresh pulp with manure, with productivities that ranged between 0.5 and $1.1 \mathrm{~L} \mathrm{~L}^{-1} \mathrm{~d}^{-1}[20]$.

The best operational condition during experimentation was for the combination of 45 days of HRT and $0.2 \mathrm{gvs}$ $\mathrm{L}^{-1} \mathrm{~d}^{-1}$ (stage III) with an average production of $277.0 \mathrm{~mL}_{\mathrm{CH} 4}$ $\mathrm{g}_{\mathrm{VS}^{-1}}$ and a productivity of $1.1 \mathrm{~L} \mathrm{~L}^{-1} \mathrm{~d}^{-1}$. These results 


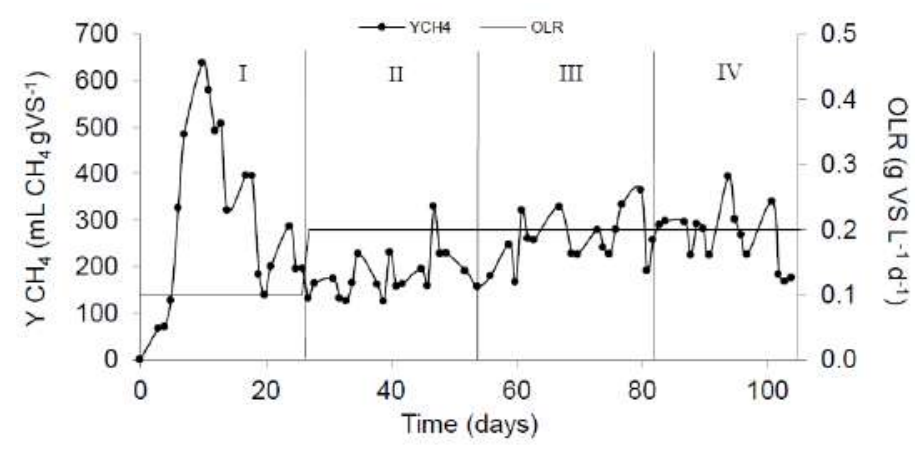

Figure 1 Coffee husk biodegradability with (CC-p) and without pre-treatment (CC). Discontinuous vertical line represents changes in feeding strategy between CC-p and CC

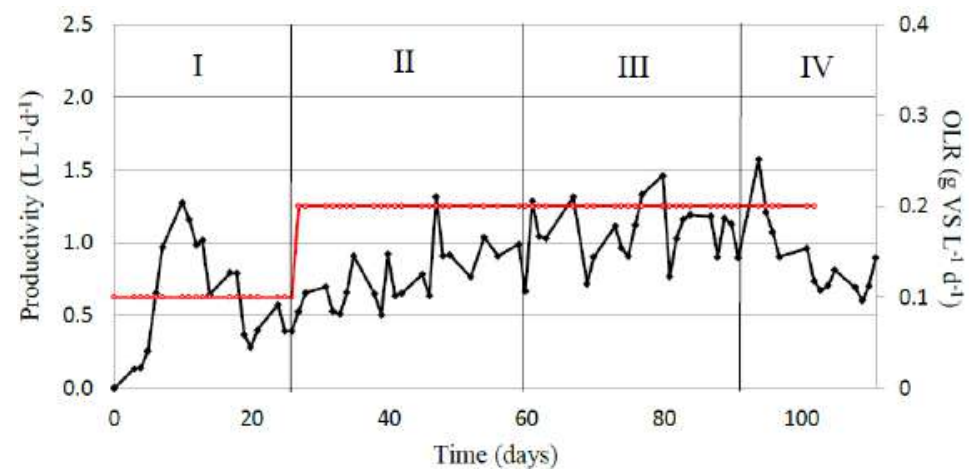

Figure 2 Methane productivity during semi-continuous assay. The red line represents the change of OLR

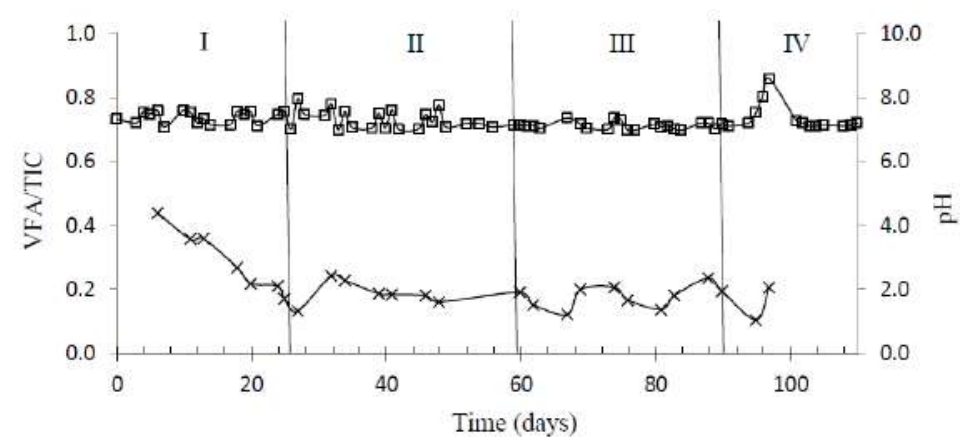

Figure $3 \mathrm{pH}(\mathrm{Q})$ values and VFA/TIC (x) ratio during mono-digestion of coffee husk with (CC-p) and without pre-treatment (CC)

are similar to those obtained for other lignocellulosic residues. In [21] is reported that maximum methane yield of corn straw digestion is $302.8 \mathrm{~mL}_{\mathrm{CH}_{4}} \mathrm{gvs}^{-1}$ when applying $2 \mathrm{gvs} \mathrm{L}^{-1} \mathrm{~d}^{-1}$. This result was associated with the ease of degradation of other components present in maize straw that facilitate the anaerobic digestion, and the absence of inhibitory components, such as polyphenols present in coffee. Another substrate such as rice straw expressed yield values between $195.0-280.0 \mathrm{~mL}_{\mathrm{CH}_{4} \text { gvs }}{ }^{-1}$ for $0.5 \mathrm{gvs}$ $\mathrm{L}^{-1} \mathrm{~d}^{-1}[22,23]$.

According to these results, $\mathrm{pH}$ and VFA/TIC values were in the expected values as recorded in Figure 3.
The $\mathrm{pH}$ was generally within the optimal range for $A D$ process $(6.5-8.2)[24,25]$. On the other hand, the VFA/TIC ratio ranged between $0.12-0.43$ indicating an adequate conversion of the substrate to methane $[6,8,14,20]$. In general, the behavior of this ratio remained stable during the experimental period demonstrating the stability of the process under the combination of HRT and the applied OLR. 


\section{Concluding remarks}

- The alkaline pre-treatment applied to coffee husk expressed a $223 \%$ of solubilization in terms of COD with an increase in methane yield obtained only under discontinuous regime.

- The accumulation of toxic substances such as polyphenols were detected when the pre-treated coffee waste was added, observing a methane yield decrement of $41 \%$ with respect to the methane yield obtained under discontinuous operation.

- For the semi-continuous operation, when non-treated coffee husk was digested, the best results were for the combination of 45 days of HRT and $0.2 \mathrm{gvs} \mathrm{L}^{-1} \mathrm{~d}^{-1}$ attaining a methane yield of $277 \mathrm{~mL}_{\mathrm{CH} 4} \mathrm{gvs}^{-1}$. It was confirmed that these residues require low hydraulic and volumetric organic loads.

\section{References}

[1] P. S. Murthy and M. M. Naidu, "Sustainable management of coffee industry by-products and value addition-a review," Resources, Conservation and Recycling, vol. 66, pp. 45-58, Sep. 2012.

[2] G. Corro, L. Paniagua, U. Pal, F. Bañuelos, and M. Rosas, "Generation of biogas from coffee-pulp and cow-dung co-digestion: Infrared studies of postcombustion emissions," Energy Conversion and Management, vol. 74, pp. 471-481, Oct. 2013.

[3] M. Selvamurugan, P. Doraisamy, and M. Maheswari, “An integrated treatment system for coffee processing wastewater using anaerobic and aerobic process," Ecological Engineering, vol. 36, no. 12, pp. 1686-1690, Dec. 2010.

[4] S. Bolado, C. Toquero, J. Martín, R. Travaini, and P. A. García, “Effect of thermal, acid, alkaline and alkaline-peroxide pretreatments on the biochemical methane potential and kinetics of the anaerobic digestion of wheat straw and sugarcane bagasse," Bioresource Technology, vol. 201, pp. 182-190, Feb. 2016.

[5] C. Sambusiti, F. Monlau, E. Ficara, H. Carrère, and F. Malpei "A comparison of different pre-treatments to increase methane production from two agricultural substrates," Applied Energy, vol. 104, pp. 62-70, Apr. 2013.

[6] M. Schroyen, H. Vervaeren, K. Raes, and S. W. V. Hulle, “Modelling and simulation of anaerobic digestion of various lignocellulosic substrates in batch reactors: Influence of lignin content and phenolic compounds ii," Biochemical Engineering Journal, vol. 134 pp. 80-87, Jun. 2018.

[7] A. K. Chandel, S. S. da Silva, and O. V. Singh, "Detoxification of lignocellulosic hydrolysates for improved bioethanol production," in Biofuel Production-Recent Developments and Prospects, M. A. D. Santos, Ed. InTech, 2011, pp. 225-246.

[8] M. Taherdanak and H. Zilouei, “Improving biogas production from wheat plant using alkaline pretreatment," Fuel, vol. 115, pp. 714-719, Jan. 2014.

[9] APHA and AWWA and WEF, Standard Methods for Examination of Water and Wastewater, 21st ed. Washington DC, USA: APHA and AWWA and WEF, 2005.
[10] Standard Test Method for Acid-Insoluble Lignin in Wood, ASTM D1106-96, 2013.

[11] J. Honorato, F. Apolinar, and G. Colot, “Composición lignocelulósica de Pinus ayacahuite Ehrenb. ex Schltdl., P. leiophylla Schlecht. y Cham. y P. herrerae Martínez," Revista Mexicana de Ciencias Forestales, vol. 7, July 2006. [Online]. Available: https://doi.org/10. 29298/rmcf.v7i34.82l

[12] Fermentation of organic materials - Characterization of the substrate, sampling, collection of material data, fermentation tests, VDI 4630 , 2006.

[13] E. M. García, I. Fernández, and A. Fuentes. (2015) Determinación de polifenoles totales por el método de folin-ciocalteu. [Online]. Available: http://hdl.handle.net/10251/52056

[14] U. Lossie and P. Pütz, "Targeted control of biogas plants with the help of FOS/TAC," Laboratory Analysis Titration Fos/Tac, Hach Lange, Tech. Rep. TIM 840/845, 2009.

[15] M. D. Ulsido, G. Zeleke, and L. Meng, “Biogas potential assessment from a coffee husk: an option for solid waste management in gidabo watershed of ethiopia," $15^{\text {th }}$ Internal Scientific Conference Engineering for Rural Development, Jelgava, Latvia, 2016.

[16] F. Shemekite and et al., "Coffee husk composting: an investigation of the process using molecular and non-molecular tools," Waste Manag., vol. 34, no. 3, March 2014. [Online]. Available: https: //doi.org/10.1016/j.wasman.2013.11.010

[17] A. K. Kivaisi, "Pretreatment of robusta coffee hulls and co-digestion with cow-dung for enhanced anaerobic digestion," Tanz. J. Sci., vol. 28, no. 2, 2002. [Online]. Available: http://dx.doi.org/10.4314/ tjs.v28i2.18349

[18] T. Amon and et al., "Biogas production from maize and dairy cattle manure-influence of biomass composition on the methane yield," Agri. Ecosyst. Environ., vol. 118, no. 1-4, January 2007. [Online]. Available: https://doi.org/10.1016/j.agee.2006.05.007

[19] M. Koyama and et al., "Effect of alkaline pretreatment on mesophilic and thermophilic anaerobic digestion of a submerged macrophyte: inhibition and recovery against dissolved lignin during semi-continuous operation," Bioresource Technology, vol. 238, August 2017. [Online]. Available: https://doi.org/10.1016/j.biortech. 2017.04.046

[20] J. F. Calzada and et al., “Biogas from coffee pulp," Biotechnology Letters, vol. 3, no. 12, December 1981. [Online]. Available: https: //doi.org/10.1007/BF00134849

[21] S. Khatri and et al., "Synergistic effect of alkaline pretreatment and fe dosing on batch anaerobic digestion of maize straw," Applied Energy, vol. 158, November 15 2015. [Online]. Available: https://doi.org/10.1016/j.apenergy.2015.08.045

[22] S. Menardo, V. Cacciatore, and P. Balsari, "Batch and continuous biogas production arising from feed varying in rice straw volumes following pre-treatment with extrusion," Bioresource Technology, vol. 180, March 2015. [Online]. Available: https://doi.org/10.1016/j. biortech.2014.12.104

[23] W. Mussoline, G. Esposito, P. Lens, A. Spagni, and A. Giordano, "Enhanced methane production from rice straw co-digested with anaerobic sludge from pulp and paper mill treatment process," Bioresource Technology, vol. 148, November 2013. [Online]. Available: https://doi.org/10.1016/j.biortech.2013.08.107

[24] L. Janke and et al., "Comparison of start-up strategies and process performance during semi-continuous anaerobic digestion of sugarcane filter cake co-digested with bagasse," Waste Management, vol. 48, February 2016. [Online]. Available: https://doi.org/10.1016/j.wasman.2015.11.007

[25] M. H. Gerardi. (2003) The microbiology of anaerobic digesters. [Wiley Library]. [Online]. Available: https://doi.org/10.1002/0471468967 